\title{
Kedudukan Putusan Mahkamah Konstitusi dan Perlindungan Hak Konstitusional Penghayat Kepercayaan
}

\author{
I Dewa Gede Palguna1
}

1Fakultas HukumUniversitas Udayana, E-mail: dewa_palguna@unud.ac.id

\begin{tabular}{l}
\hline Info Artikel \\
\hline Masuk:13 Juli 2021 \\
Diterima:25 September 2021 \\
Terbit:30 September 2021 \\
Keywords: \\
Constitutional Court; \\
Constitutional Rights; Followers of \\
Indigenous Beliefs; Discrimination \\
\\
\\
\\
10.24843/JMHU.2021.v10.i03.p06 \\
Kata kunci: \\
Mahkamah Konstitusi; Hak \\
Konstitusional; Penganut \\
Kepercayaan; Diksriminasi \\
Corresponding Author: \\
I Dewa GedePalguna, E-mail: \\
dewa palguna@unud.acid \\
DOI: \\
\end{tabular}

\begin{abstract}
This study is a normative legal research which aims at discovering answers of two fundamental questions, namely, first, how is the status of the decisions of the Indonesia's Constitutional Court according to the country's constitutional system; secondly, what legal remedies may be pursued by the Indonesian citizens who are followers of indigenous beliefs whose constitutional rights to embrace such beliefs remain infringed despite there has been the decision of the Indonesia's Constitutional Court Number 97/PUU-XIV/2016 which confirms the constitutional guarantee of such beliefs. With respect to the first issue, the study found that the status of the Court's decision was equal to Law because it was the product of a negative legislator. In addition, because the Court was also the interpreter of the Constitution (UUD 1945), then its decision was the Court's constitutional interpretation concerning the issue at hand. As to the second issue, the study found that the followers of indigenous beliefs could file several legal remedies, namely citizen suit; class action; individual law suit; and submitting a formal complaint to the president, as the highest chief administrative officer, asking the president to reprimand its subordinates and to instruct them to observe the Court decision.

\begin{tabular}{l} 
Abstrak \\
\hline Kajian ini adalah sebuah penelitian hukum normatif yang \\
bermaksud menemukan jawaban atas dua pertanyaan mendasar \\
yaitu, pertama, bagaimana kedudukan dari putusan Mahkamah \\
Konstitusi menurut sistem ketatanegaraan Indonesia; kedua, \\
jalan hukum apa yang dapat ditempuh oleh warga negara \\
Indonesia penghayat kepercayaan yang hak konstitusionalnya \\
untuk menganut keyakinan tersebut tetap dirugikan meskipun \\
telah ada Putusan Mahkamah Konstitusi Nomor 97/PUU- \\
XIV/2016 yang menegaskan jaminan konstitusi terhadap hak \\
tersebut. Terhadap isu pertama, kajian ini menemukan jawaban \\
bahwa kedudukan putusan Mahkamah Konstitusi adalah setara \\
dengan undang-undang karena merupakan produk dari negative \\
legislator. Sebagai tambahan, oleh karena Mahkamah Konstitusi \\
juga merupakan penafsir Konstitusi (UUD 1945), maka \\
putusannya adalah penafsiran konstitusional Mahkamah \\
terhadap masalah yang sedang ditanganinya. Terhadap isu \\
kedua, kajian ini menemukan jawaban bahwa penghayat \\
kepercayaan dapat mengajukan beberapa upaya hukum, yaitu \\
gugatan warga negara, gugatan kelompok, gugatan individual, \\
dan membuat pengaduan resmi kepada presiden, selaku kepala \\
pemerintahan tertinggi, dan meminta agar presiden
\end{tabular}
\end{abstract}


memperingatkan bawahannya serta memerintahkan mereka untuk mematuhi putusan Mahkamah Konstitusi.

\section{Pendahuluan}

Empat tahun setelah Mahkamah Konstitusi menjatuhkan putusannya yang dianggap fenomenal, yaitu Putusan Nomor 97/PUU-XIV/2016, ternyata tidak serta-merta meniadakan praktik diskriminasi kepada warga negara Indonesia penghayat kepercayaan terhadap Tuhan Yang Mahaesa (selanjutnya disingkat "penghayat kepercayaan"). Putusan di atas adalah putusan tentang pengujian beberapa pasal dalam Undang-Undang Nomor 23 Tahun 2006 tentang Administrasi Kependudukan sebagaimana telah diubah dengan Undang-Undang Nomor 24 Tahun 2013 tentang Perubahan Atas Undang-Undang Nomor 23 Tahun 2006 tentang Administrasi Kependudukan (selanjutnya disebut UU Adminduk) terhadap Undang-Undang Dasar Negara Republik Indonesia Tahun 1945 (selanjutnya disebut UUD 1945) yang diajukan oleh beberapa orang warga negara Indonesia penghayat kepercayaan (c.q. penghayat kepercayaan Marapu dari Sumba, penghayat kepercayaan Parmalim dan Ugamo Bangso Batak dari Sumatera Utara, dan pengayat kepercayaan Sapto Darmo dari Jawa Tengah).

Adapun pasal-pasal UU Adminduk yang dimohonkan pengujian tersebut adalah Pasal 61 ayat (1) dan ayat (2) serta Pasal 64 ayat (1) dan ayat (5) UU Adminduk. Pasal 61 ayat (1) mengatur "KK memuat keterangan mengenai kolom nomor KK, nama lengkap kepala keluarga dan anggota keluarga, NIK, jenis kelamin, alamat, tempat lahir, tanggal lahir, agama (garis bawah oleh penulis), pendidikan, pekerjaan, status perkawinan, status hubungan dalam keluarga, kewarganegaraan, dokumen imigrasi, nama orang tua." Sementara itu, Pasal 61 ayat (2) menegaskan "bagi penduduk yang belum diakui agamanya sesuai dengan peraturan perundang-undangan atau bagi penghayat kepercayaan maka kolom agama pada KK itu tidak diisi alias dikosongkan namun tetap dilayani dan dicatat dalam data base kependudukan." Adapun Pasal 64 ayat (1) memuat ketentuan sebagaimana dimaksud Pasal 61 ayat (1) mengenai isian data pada KTP termasuk kolom "agama." Sedangkan Pasal 64 ayat (5) memuat ketentuan yang serupa pada Pasal 61 ayat (2) yaitu "elemen data penduduk tentang agama bagi penduduk yang agamanya belum diakui sesuai dengan peraturan perundang-undangan atau bagi penghayat kepercayaan tidak diisi tetapi tetap dilayani dan dicatat dalam database kependudukan."

Mahkamah Konstitusi lewat putusan di atas mengabulkan untuk seluruhnya permohonan ini. Secara garis besar, ada dua hal penting yang termuat dalam diktum atau amar putusan Mahkamah Konstitusi tersebut. Pertama, Mahkamah menyatakan bahwa kata 'agama' dalam Pasal 61 ayat (1) dan Pasal 64 ayat (1) UU Adminduk bertentangan dengan UUD 1945 dan tidak mempunyai kekuatan hukum mengikat secara bersyarat sepanjang tidak diartikan termasuk 'kepercayaan'. Kedua, Mahkamah menyatakan Pasal 61 ayat (2) dan Pasal 64 ayat (5) UU Adminduk bertentangan dengan UUD 1945 dan tidak mempunyai kekuatan hukum mengikat. Konsekuensi dari putusan Mahkamah Konstitusi di atas ialah, pertama, tidak lagi ada alasan hukum untuk tidak mencantumkan "penghayat kepercayaan" bagi warga negara Indonesia penghayat kepercayaan pada kolom agama di KK dan KTP; kedua, tidak boleh lagi 
ada pembedaan perlakuan terhadap warga negara Indonesia atas dasar agama atau kepercayaan terhadap Tuhan Yang Maha Esa yang dianutnya.

Jadi, secara normatif, dengan adanya putusan Mahkamah Konstitusi di atas seharusnya tidak ada lagi hambatan bagi warga negara Indonesia penghayat kepercayaan bukan hanya dalam hal pengakuan akan identitasnya sebagai penghayat kepercayaan yang harus secara tegas tercantum di KK maupun KTP, tetapi juga dalam segala hal yang merupakan turunan dari atau berkait dengan pemenuhan hak konstitusionalnya sebagai penghayat. Namun, kenyataan yang terjadi dalam praktik ternyata kebalikannya. Harian Kompas sempat berturut-turut menurunkan reportase tentang berbagai hambatan yang dihadapi oleh para penghayat dalam kehidupan mereka. Puan Hayati, sebuah organisasi perempuan penghayat kepercayaan menyatakan bahwa putusan Mahkamah Konstitusi di atas belum sampai ke tingkat kelurahan atau kabupaten/kota. Dian Jennie Cahyawati, ketua Puan Hayati Pusat, mengatakan kalau organisasinya masih sering menerima laporan bahwa ada daerah yang belum paham putusan tersebut. ${ }^{1}$

Sementara itu, Naen Soeryono, Ketua Persatuan Warga Sapta Darma (Persada) menyatakan masih terlihat kurangnya pemahaman yang kurang dari aparatur pemerintah di daerah-daerah mengenai hak penghayat kepercayaan. Menurutnya, ada aparat yang tidak mau tahu dan menganggap hanya ada enam agama. "Masih ada ketidaksenangan terhadap penghayat kepercayaan meski sudah ada putusan MK," katanya. 2 Penghayat kepercayaan Sunda Wiwitan juga menghadapi masalah diskriminasi yang tak kalah seriusnya. Pasangan calon pengantin yang bernama Ajat Sudrajat dan Anih Kurniasih perkawinannya yang dilaksanakan sesuai dengan keyakinan Sunda Wiwitan terancam tak diakui negara, sebab meskipun tercatat secara adat, perkawinan tersebut terancam tak bisa dicatatkan di Kantor Urusan Agama. Kekhawatiran itu disampaikan Ajat karena bercermin dari perkawinan kakaknya dua tahun sebelumnya serta perkawinan orang tuanya sekitar dua dekade yang lalu. Perkawinan mereka tidak mendapatkan akta perkawinan. Hal ini berdampak luas sebab mereka menjadi sulit mengurus kartu keluarga, akta kelahiran anak, dan lainlain. ${ }^{3}$ Dokumen-dokumen tersebut sangat vital untuk dapat menikmati pelayanan yang diberikan negara.

Ada dua isu hukum yang merupakan persoalan konstitusional mendasar yang timbul dari kenyataan empirik di atas. Pertama, perihal kedudukan putusan Mahkamah Konstitusi dalam sistem ketatanegaraan Indonesia menurut UUD 1945. Kedua, upaya hukum yang dapat ditempuh oleh warga negara Indonesia penghayat kepercayaan yang hak konstitusionalnya sebagai penghayat kepercayaan tetap dirugikan meskipun telah ada Putusan Mahkamah Konstitusi Nomor 97/PUU-XIV/2016.

Kedua persoalan konstitusional mendasar ini penting untuk diteliti atau dikaji setidaktidaknya karena dua alasan. Pertama, substansi persoalan dari kedua isu hukum yang bertolak fakta-fakta empirik yang dialami oleh para penghayat kepercayaan tersebut

1 "Para Penghayat Kepercayaan Masih Terpinggirkan - Kompas.Id," accessed September 24, 2021, https://www.kompas.id/baca/dikbud/2021/05/31/para-penghayat-kepercayaanmasih-terpinggirkan.

2 Ibid.

3 "Penghayat Kepercayaan: Sulitnya Kami Menikah Secara "Resmi" - Kompas.Id," accessed September 24, 2021, https://www.kompas.id/baca/dikbud/2021/05/31/penghayatkepercayaan-sulitnya-kami-menikah-secara-resmi. 
menunjukkan tidak ditaatinya, setidak-tidaknya masih ada keengganan untuk menaati, prinsip atau asas mendasar dalam negara demokrasi yang berdasar atas hukum yakni prinsip atau asas supremasi konstitusi (supremacy of the constitution) yang intinya ialah bahwa praktik penyelenggaraan negara harus senantiasa mengacu pada dan tidak boleh bertentangan dengan konstitusi sebagai hukum fundamental atau hukum tertinggi. Putusan Mahkamah Konstitusi (MK), yang oleh Konstitusi diberi kewenangan untuk menafsirkan UUD 1945, pada hakikatnya berisikan penafsiran Mahkamah terhadap ketentuan Konstitusi, in casu yang berkenaan dengan "hak atas kebebasan beragama dan hak atas kebebasan menganut keyakinan." Melalui putusanputusannya yang pada hakikatnya berisikan penafsiran konstitusi itulah Mahkamah Konstitusi menegakkan prinsip supremasi konstitusi. Dengan kata lain, penegakan prinsip atau asas supremasi konstitusi itu dilakukan melalui pemberlakuan prinsip supremasi pengadilan (judicial supremacy). ${ }^{4}$ Selain itu, fakta-fakta empirik di atas sekaligus menunjukkan tidak adanya sinkronisasi antarkaidah hukum dalam pelaksanaannya, dalam hal ini antara kaidah hukum yang ada dalam undang-undang dan kaidah hukum yang tertuang pada putusan hakim (c.q. MK) yang telah memberikan penafsiran perihal syarat untuk dapat dikatakan konstitusionalnya kaidah undang-undang yang bersangkutan. Padahal, sebagaimana akan tampak pada uraian selanjutnya, putusan MK memiliki kedudukan yang sama dengan undangundang sebab MK adalah negative legislator.

Kedua, substansi persoalan dari kedua isu hukum tersebut langsung berkenaan dengan salah satu fundamen constitutional democratic state yang tiada lain merupakan negara yang dicita-citakan sekaligus diamanatkan oleh Pembukaan UUD 1945 sebagai penjabaran lebih lanjut dari Kemerdekaan Kebangsaan Indonesia. Penjelasannya adalah sebagai berikut: "Pembukaan UUD 1945, alinea keempat, menyatakan bahwa Kemerdekaan Kebangsaan Indonesia itu (harus) disusun dalam suatu UndangUndang Dasar Negara Indonesia yang terbentuk dalam suatu susunan Negara Republik Indonesia yang berkedaulatan rakyat." Negara yang menegakkan kedaulatan rakyat hanya ada dalam negara demokrasi. Sebab hanya dalam negara demokrasilah rakyat memegang kekuasaan tertinggi ${ }^{5}$. Pembukaan (preamble) dari suatu konstitusi, menurut Hans Kelsen, adalah "a solemn introduction" "(suatu pengantar yang bersifat khidmat) yang mengekspresikan ide-ide politik, moral, dan religius yang dicita-citakan untuk diwujudkan oleh konstitusi itu) ${ }^{6} . "$ Oleh sebab itu, secara doktriner, implementasi dari suatu amanat pembukaan konstitusi ke dalam substansi (normanorma) konstitusi adalah keharusan. Lebih-lebih jika mempertimbangkan corak atau karakter Pembukaan UUD 1945 yang bercorak programatik. Suatu pembukaan konstitusi yang bercorak programatik memuat rumusan nilai-nilai politik yang diarahkan untuk diimplementasikan ke dalam norma-norma (pasal-pasal) konstitusi itu. Oleh karena itu, suatu pembukaan konstitusi yang berkarakter programatik sesungguhnya juga berarti memuat arahan perihal bagaimana konstitusi itu harus ditafsirkan. ${ }^{7}$

${ }^{4}$ Harkrisnowo, Harkristuti, and et.al, Meretas Khazanah Hukum Indonesia (Depok: Rajawali Pers, 2020).

${ }^{5}$ David Held, Models of Democracy (Cambridge: Polity Press, 1997).

${ }^{6}$ Hans Kelsen, "General Theory of Law And State, Translated by Anders Wedberg, New York: Russell \& Russell A Division of Atheneum Publishers" (Inc, 1961).

${ }^{7}$ H Th J F van Maarseveen and Ger F M van der Tang, Written Constitutions: A Computerized Comparative Study (Brill, 1978). 
Namun, oleh karena demokrasi, dengan segala kelebihannya, 8 ternyata mengandung "cacat bawaan" sehingga mudah dimanipulasi (terutama karena "ketergantungannya" kepada suara terbanyak), ${ }^{9}$ maka dalam perkembangannya gagasan demokrasi bertemu dengan gagasan negara hukum sehingga melahirkan perkembangan terkini yang disebut constitutional democratic state. ${ }^{10}$ Maka daripada itu, amanat Pembukaan UUD 1945 alinea keempat tersebut, oleh MPR (ketika melakukan perubahan UUD 1945), dimaknai sebagai amanat untuk mewujudkan constitutional democratic state. Pemaknaan tersebut lalu dijabarkan dan sekaligus lebih dieksplisitkan dalam Pasal 1 ayat (2) UUD 1945 menyatakan, "Kedaulatan berada di tangan rakyat dan dilaksanakan menurut Undang-Undang" dan ayat (3) UUD 1945 dinyatakan, "Indonesia adalah negara hukum."

Salah satu syarat yang tidak dapat dihilangkan dari negara demokrasi yang berdasar atas hukum adalah adanya jaminan dan perlindungan terhadap HAM, lebih-lebih tatkala hak-hak tersebut telah dituangkan ke dalam konstitusi sehingga menjadi hakhak konstitusional. Durga Das Basu menyatakan sebagai hak konstitusional berarti hak itu menjadi bagian dari konstitusi, karena konstitusi adalah hukum fundamental yang berlaku dalam suatu negara maka hak konstitusional adalah bagian dari hukum fundamental tersebut sehingga hak-hak itu pun memiliki sifat fundamental. Tindakan negara (melalui cabang-cabang kekuasaannya) yang bertentangan dengan hukum fundamental tersebut, yang di dalamnya termasuk hak-hak konstitusional, harus dibatalkan oleh pengadilan. ${ }^{11}$

Baik hak untuk menganut agama, yang tentu saja tidak boleh dibatasi pada agama tertentu, maupun hak atas kebebasan meyakini kepercayaan adalah hak konstitusional. Hal itu ditegaskan dalam Pasal 28I ayat (1) dan Pasal 28E ayat (2) UUD 1945. Oleh karena itu, sebagai constitutional democratic state, negara wajib menghormati, melindungi, dan memenuhi hak konstitusional dimaksud.

Tujuan dari Penelitian ini yang pertama, untuk mengetahui, memahami dan menganalisa kedudukan putusan Mahkamah Konstitusi dalam sistem ketatanegaraan Indonesia menurut UUD 1945. Kedua, untuk memahami, menganalisa dan mengelaborasi upaya hukum yang dapat ditempuh oleh warga negara Indonesia penghayat kepercayaan yang hak konstitusionalnya sebagai penghayat kepercayaan tetap dirugikan meskipun telah ada Putusan Mahkamah Konstitusi Nomor 97/PUUXIV/2016.

Penelitian terdahulu pernah dilakukan oleh Daulat Nathanael Banjarnahor dan Firinta Togatorop tahun 2021 dengan judul artikel "Efektivitas Perlindungan Hak Konstitusional Penghayat Kepercayaan Parmalim Pra Dan Pasca Putusan Mahkamah Konstitusi RI No. 97/PUU-XIV/2016" dengan fokus kajian yaitu efektivitas perlindungan hukum hak konstitusional penghayat kepercayaan parmalim pra dan pasca Putusan Mahkamah Konstitusi RI No. 97/PUU-XIV/2016 serta faktor

\footnotetext{
${ }^{8}$ Robert A Dahl, "Perihal Demokrasi, Terj," A. Rahman Zainuddin, Jakarta: Yayasan. Obor Indonesia, 2001.

${ }^{9}$ William, Great Political Thinkers, Plato to the Present, Third Edit (New York-Chicago-San Francisco-Toronto: Holt, Rinehart and Winston, 1960).

10 I Dewa Gede Palguna, Pengaduan Konstitusional (Constitutional Complaint): Upaya Hukum Terhadap Pelanggaran Hak-Hak Konstitusional Warga Negara (Jakarta: SinarGrafika, 2013).

${ }^{11}$ Durga Das Basu, Bhagabati Prosad Banerjee, and Ashish Kumar Massey, Human Rights in Constitutional Law (New Delhi-Nagpur-Agra: Wadhwa \& Company, 2003).
} 
pendukung dan penghambat efektivitas hukum perlindungan hak konstitusional penghayat kepercayaan parmalim pra dan pasca Putusan Mahkamah Konstitusi RI No. 97/PUU-XIV/2016. Penelitian serupa juga pernah dilakukan oleh Moh Bhayu Surya Andhika pada tahun 2019 dengan judul artikel “Perlindungan Hukum terhadap Hak Konstitusional Warga Negara Penganut Kepercayaan" dengan fokus kajian yaitu mengkaji perlindungan hukum terhadap hak konstitusional warga negara penghayat kepercayaan yang tertuang dalam putusan Mahkamah Konstitusi Nomor 97/PUUXIV/2016. Serta penelitian yang dilakukan oleh Muhammad Yusrizal Adi Syaputra dan Mirza Nasution pada tahun 2019 dengan judul artikel "Pemenuhan Hak Konstitusional Masyarakat Penganut Kepercayaan Lokal Dalam Pemilihan Umum" dengan fokus kajian yaitu kedudukan masyarakat penganut kepercayaan lokal dalam sistem kewarganegaraan Indonesia dan perlindungan hak konstitusionalpenganut aliran kepercayaan lokal dalam pemilihan umum berdasarkan sistem ketatanegaraan indonesia. Berdasarkan paparan tersebut terdapat adanya persamaan dari fokus kajian yaitu mengenai hak konstitusional penghayat kepercayaan, namun terdapat perbedaan fokus kajian. Penelitian ini mengkaji 2 (dua) pokok permasalahan yaitu kedudukan putusan Mahkamah Konstitusi dalam sistem ketatanegaraan Indonesia menurut UUD 1945 dan upaya hukum yang dapat ditempuh oleh warga negara Indonesia penghayat kepercayaan yang hak konstitusionalnya sebagai penghayat kepercayaan tetap dirugikan meskipun telah ada Putusan Mahkamah Konstitusi Nomor 97/PUU-XIV/2016.

\section{Metode Penelitian}

Penelitian ini adalah penelitian hukum normatif bukan semata-mata karena alasan bahwa isu hukum yang diteliti adalah berkait dengan asas-asas hukum maupun taraf sinkronisasi kaidah hukum 12 melainkan juga karena kebenaran yang hendak ditemukan dari isu hukum yang diteliti/dikaji adalah kebenaran pragmatik atau kebenaran konsensus sejawat sekeahlian ${ }^{13}$ dan sekaligus kebenaran koherensi karena berusaha menemukan jawaban atas pertanyaan apakah suatu tindakan sesuai dengan norma atau prinsip hukum. ${ }^{14}$ Penelitian ini juga merupakan penelitian hukum normatif dilihat dari kegunaannya. Menurut Mersky, kegunaan penelitian hukum normatif ialah bahwa hasil kajiannya (mengidentifikasi dan menemukan informasi) dibutuhkan untuk mendukung pembuatan keputusan hukum. ${ }^{15}$ Sifat normatif dari penelitian ini juga dapat dilihat dalam perspektif yang lebih luas, sebagaimana dikatakan Putman, yaitu bahwa kajiannya merupakan proses menemukan hukum yang berlaku terhadap masalah masyarakat, baik individual maupun kolektif. ${ }^{16}$

Karena merupakan penelitian hukum normatif maka data yang digunakan adalah berupa data sekunder yang terdiri atas beberapa bahan hukum, baik bahan hukum

\footnotetext{
${ }^{12}$ Soerjono Soekanto and Sri Mamudji, Penelitian Hukum Normatif, cetakan ke (Jakarta: Raja Grafindo Persada, 1990).

${ }^{13}$ Phillipus M. Hadjon and Tattiek Sri Djatmiati, Argumentasi Hukum (Yogyakarta: Gadjah Mada University Press, 2016).

${ }_{14}$ Mahmud Marzuki, Penelitian Hukum: Edisi Revisi (Prenada Media, 2017).

${ }_{15}$ Roy M. Mersky and Donald J. Dunn, Fundamentals of Legal Researd, Eight Edit (New York:

Foundation Press, 2002).

${ }^{16}$ William H, Legal Research (New York: Thomson Delmar Learning, 2006).
} 
primer, bahan hukum sekunder, maupun bahan hukum tertier. ${ }^{17}$ Atau, jika mengikuti pengelompokan bahan hukum dalam legal research di negara-negara common law, khususnya Amerika Serikat, bahan hukum yang digunakan dalam penelitian ini terdiri atas, pertama, bahan hukum dari kategori primary authority, khususnya yang berupa primary mandatory (binding) authority (di antaranya Konstitusi, c.q. UUD 1945, undangundang, putusan pengadilan) maupun primary persuasive (non binding) authority (yaitu bahan hukum yang dirujuk oleh hakim dalam mempertimbangkan suatu kasus namun ia tidak terikat untuk mengikuti rujukan itu); kedua, bahan hukum dari kategori secondary authority, yaitu semua bahan hukum, di luar kategori primary authority, yang sifatnya meringkaskan, mengumpulkan, mengomentari, menginterpretasikan, atau

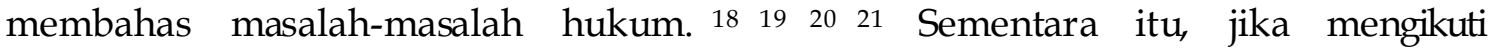
pengelompokan bahan hukum menurut Statsky maka bahan hukum yang digunakan dalam penelitian ini terdiri atas opinion atau case, statute atau legislation, constitution, dan rules of court. ${ }^{22}$

Adapun pendekatan yang digunakan dalam penelitian ini ialah pendekatan konseptual, pendekatan analitis, dan pendekatan kasus dengan ditunjang oleh penelurusan bahan hukumnya melalui teknik studi dokumen yang kemudian diolah melalui teknik analisa kualitatif.

\section{Hasil dan Pembahasan}

\subsection{Kedudukan putusan Mahkamah Konstitusi dalam sistem ketatanegaraan Indonesia menurut UU 1945}

Sebelum menelaah kedudukan putusan Mahkamah Konstitusi dalam sistem ketatanegaraan Indonesia, ada baiknya untuk meninjau terlebih dahulu dasar pemikiran yang melandasi pembentukan MK (atau sebutan lainnya) dalam perkembangan pemikiran dan praktik ketatanegaraan di seluruh dunia. ${ }^{23}$ Singkatnya, gagasan membentuk MK merupakan kritik terhadap prinsip supremasi parlemen yang merupakan inti dari sistem pemerintahan parlementer. Sebagaimana diketahui, sistem parlementer lahir sebagai reaksi terhadap (dan berhasil mengakhiri) kekuasaan absolut raja dalam sistem monarki absolut. Sistem parlementer dan prinsip supremasi parlemennya memeroleh pembenaran teoretiknya, antara lain, dari Rousseau dengan ajaran "Kontrak Sosial”-nya. Menurut Rousseau, rakyat memiliki kedudukan supreme. Parlemen adalah representasi rakyat maka ia pun memiliki sifat supreme. ${ }^{24}$

Namun, sebagaimana dikatakan Tom Ginsburg, praktik sistem parlementer dengan prinsip supremasi parlemennya ternyata juga gagal mencegah lahirnya ancaman

\footnotetext{
17 Soekanto and Mamudji, Penelitian Hukum Normatif.

18 Mersky and Dunn, Fundamentals of Legal Research.

${ }^{19}$ Amy E Sloan, Basic Legal Research: Tools and Strategies (Wolters Kluwer, 2018).

${ }^{20}$ Beth Walston-Dunham, Practical Legal Research: Skills \& Strategies for the Legal Assistant (Delmar Pub, 1995).

${ }^{21}$ Steve Barber and Mark A McCormick, Legal Research (Delmar Pub, 1996).

22 William P Statsky, Legal Research and Writing: Some Starting Points (West Publishing Company, 1993).

${ }^{23}$ I Palguna and Dewa Gede, "Mahkamah Konstitusi: Dasar Pemikiran," Kewenangan, Dan Perbandingan Dengan Negara Lain, Konpress, Jakarta, 2018.

24 Jean-Jacques Rousseau, “The Social," Contract. London: Penguin Books, 1968.
} 
terhadap demokrasi. Jika dalam sistem monarki absolut, sebelum lahirnya sistem pemerintahan parlementer, ancaman itu datang dari raja, dalam perkembangannya ancaman terhadap demokrasi datang justru dari rezim yang awalnya terpilih secara demokratis tetapi dalam perjalanan berubah menjadi rezim fasis. Eropa pun terjerumus ke dalam Perang Dunia II. Dengan kata lain, ancaman terhadap demokrasi justru datang dari dalam. Ide membentuk mahkamah konstitusi dianggap sebagai jawaban yang tepat untuk menangkal penggerotan demokrasi dari dalam tersebut. ${ }^{25}$

Pandangan Ginsburg yang bertolak dari fakta-fakta pra dan pasca-Perang Dunia II memang benar adanya. Tetapi ide untuk membentuk mahkamah konstitusi itu bukanlah timbul karena pengalaman Perang Dunia II (semata-mata). Sebab, mahkamah konstitusi pertama justru telah berdiri di awal Abad ke-20, jauh sebelum meletusnya Perang Dunia II, yakni Mahkamah Konstitusi Austria (Bundesverfassungsgerichtshof) pada tahun 1920 yang diadopsi bersamaan dengan diterimanya Konstitusi 1920 yang mendirikan Republik Austria pasca-runtuhnya Kekaisaran Austro-Hungaria sebagai akibat dari Perang Dunia I. Meskipun ide awal pembentukan Mahkamah Konstitusi Austria itu datang dari Karl Renner, Ketua Partai Demokrat Sosial Austria (yang kemudian menjadi Kanselir Austria pertama), orang yang mewujudkan ide tersebut menjadi kenyataan adalah Hans Kelsen, yang tidak lain adalah sahabat Renner. Kelsen mengonstruksikan lembaga ini sebagai pelindung atau pengawal konstitusi dengan tugas utama adalah menguji konstitutionalitas undangundang. 2627

Jika dipelajari secara lebih saksama, gagasan Kelsen tentang pentingnya mahkamah konstitusi itu bertolak dari dua proposisi (dalil) dasar. Proposisi pertama: konstitusi harus benar-benar ditaati dan ketaatan itu sungguh-sungguh terlihat atau dilaksanakan dalam praktik. Proposisi kedua: untuk menjamin ketaatan kepada konstitusi perlu dibentuk organ atau lembaga tersendiri yang berwujud pengadilan yang terpisah dari sistem peradilan biasa. Kedua proposisi tersebut konsisten dengan cara pandang atau ajaran Kelsen tentang hukum yang positivistik dan sangat menekankan pada kepastian hukum. Bagi Kelsen, tidak ada hukum di luar hukum positif sebab hukum dibuat oleh perbuatan manusia dan dibatalkan juga oleh perbuatan manusia. Hukum terdiri atas norma-norma dengan susunan hierakisnya. Kelsen menegaskan bahwa "Norma yang lebih rendah mendapatkan validitas atau keabsahannya dari norma yang lebih tinggi, demikian seterusnya hingga sampai pada puncak hierarki norma yang disebut norma dasar (grundnorm) yang sudah berada di luar hukum positif karena ia merupakan hipotesis asal yang menjadi sumber validitas dari seluruh norma hukum positif." Grundnorm bukan hukum positif karena bukan buatan manusia melainkan "praduga pemikiran" (presupposition of thought) atau "aturan tertinggi yang didalilkan" (postulated ultimate rule). Adapun norma hukum positif tertinggi adalah konstitusi. Penjelasan ini menjawab proposisi pertama. Bagaimana dengan proposisi kedua, mengapa untuk menjamin ketaatan terhadap konstitusi itu harus dibentuk pengadilan tersendiri (c.q. mahkamah konstitusi). Ini pun dapat dijelaskan berdasarkan cara pandang atau ajaran Kelsen tentang hukum yang

25 Tom Ginsburg, Judicial Review in New Democracies: Constitutional Courts in Asian Cases (Cambridge University Press, 2003).

26 Palguna and Gede, "Mahkamah Konstitusi: Dasar Pemikiran."

27 Jimly Asshiddiqie and Ahmad Syahrizal, Peradilan Konstitusi Di Sepuluh Negara (Sekretariat Jenderal Mahkamah Konstitusi, 2006). 
sesungguhnya secara implisit juga sudah terjawab melalui penjelasan terhadap proposisi pertama di atas. Tegasnya, pandangan Kelsen yang memandang hukum sebagai sekumpulan norma hukum positif yang bertingkat-tingkat di mana konstitusi berada pada posisi sebagai norma hukum positif tertinggi melahirkan konsekuensi yang bersifat mendasar, yaitu mutlaknya kehadiran satu lembaga negara untuk menjamin konsistensi dan kesatuan penafsiran terhadap konstitusi demi terciptanya kepastian hukum. Lembaga demikian tiada lain adalah mahkamah konstitusi. Dalam tradisi cicil law, fungsi menjamin konsistensi dan kesatuan penafsiran terhadap konstitusi itu tidak mungkin diserahkan kepada pengadilan biasa, "sebagaimana yang dipraktikkan di negara-negara common law, khususnya Amerika Serikat." Alasannya, karena di negara-negara civil law tidak dikenal adanya prinsip stare decisis atau precedent. Sedangkan negara-negara common law tidak ada kebutuhan untuk memiliki atau membentuk pengadilan khusus guna membangun kesatuan penafsiran konstitusi melainkan cukup melalui pengadilan biasa sebab kesatuan penafsiran itu dijamin oleh bekerjanya prinsip state decisis atau precedent. Melalui asas ini, jika suatu masalah telah diputuskan oleh pengadilan sebelumnya atau oleh pengadilan yang lebih tinggi maka pengadilan berikutnya atau pengadilan yang lebih rendah harus mengikuti putusan tersebut. 2829 Sementara di negara-negara civil law, masing-masing hakim memiliki keleluasaan penuh dalam memutus perkara sehingga jika penafsiran konstitusi diserahkan kepada pengadilan biasa, peluang terjadinya disparitas penafsiran akan sangat terbuka dan itu berarti tidak ada kepastian hukum. 3031

Di luar alasan kepastian hukum, alasan lain perlunya dibentuk pengadilan tersendiri untuk melaksanakan tugas mengawal konstitusi, khususnya tugas melakukan pengujian konstitusionalitas undang-undang ialah karena pengadilan dimaksud (yaitu mahkamah konstitusi) bukanlah pengadilan biasa. Sebab ia berwenang 'membatalkan' undang-undang yang dibuat oleh pembentuk undang-undang (positive legislator). Dengan memiliki kewenangan tersebut, secara esensial, mahkamah konstitusi sesungguhnya adalah juga legislator namun dalam arti negatif. Karena itulah ia disebut sebagai negative legislator. Itulah alasan pengisian jabatan hakim konstitusi sama sekali berbeda dengan cara pengisian jabatan hakim biasa. ${ }^{32}$ Pandangan Kelsen ini sejalan dengan pandangan kalangan sarjana hukum Jerman yang berpendapat bahwa kewenangan utama mahkamah konstitusi, yaitu judicial review alias menguji undang-undang, adalah kewenangan yang bersifat politik. Oleh karena itu tidak

${ }^{28}$ Bryan A Garner, "Black's Law Dictionary Seventh Edition,(St," Paul Minn:West Publishing Co, 1999.

${ }^{29}$ Stare decisis adalah doktrin preseden yang berdasarkan doktrin tersebut suatu pengadilan perlu (terikat) untuk mengikuti putusan-putusan pengadilan sebelumnya tatkala masalah yang sama muncul lagi dalam proses pengadilan ("The doctrine of precedent, under which it is necessary for a court to follow earlier judicial decisions when the same points arise again in litigation");

${ }^{30}$ Untuk analisis yang lebih komprehensif mengenai kedua proposisi yang menjadi dasar pemikiran Kelsen menggagas pentingnya mahkamah konstitusi Palguna, Pengaduan Konstitusional (Constitutional Complaint): Upaya Hukum Terhadap Pelanggaran Hak-Hak Konstitusional Warga Negara.

${ }^{31}$ Khusus untuk menjelaskan tidak mungkinnya negara-negara civil law menerapkan model pengujian konstitusional ala Amerika Serikat, Kelsen secara khusus menulis artikel tersendiri; Hans Kelsen, "Judicial Review of Legislation: A Comparative Study of the Austrian and the American Constitution," The Journal of Politics 4, no. 2 (1942): 183-200.

32 Kelsen, "General Theory of Law And State, Translated by Anders Wedberg, New York: Russell \& Russell A Division of Atheneum Publishers." 
mungkin diberikan kepada pengadilan biasa yang tugasnya justru untuk melaksanakan ketentuan undang-undang, bukan mengujinya. ${ }^{33}$

Kendatipun benar bahwa Kelsen adalah konseptor mahkamah konstitusi (dengan mengkonstruksikan kewenangan menguji konstitusionalitas undang-undang sebagai kewenangan utamanya), ${ }^{343536}$ gagasan bahwa pengadilan mempunyai kewenangan menguji konstitusionalitas undang-undang bukanlah murni gagasan Kelsen. Gagasan demikian telah ada dan dipraktikan sejak lebih dari seabad sebelumnya yaitu ketika Mahkamah Agung Amerika Serikat menjatuhkan putusan dalam perkara yang sangat terkenal, Marbury v. Madison (1803). Pada saat itu Mahkamah Agung Amerika Serikat dipimpin oleh Chief Justice John Marshall. Dalam putusan yang disebut-sebut ditulis sendiri oleh John Marshall itu, Mahkamah Agung Amerika Serikat menyatakan yang pada intinya menegaskan bahwa konstitusi adalah hukum tertinggi, supreme law, sebagaimana ditegaskan oleh Supremacy Clause dalam Bab IV paragraf 2 Konstitusi Amerika Serikat. Supremacy Clause tersebut menegaskan, Tidak boleh ada undangundang, baik undang-undang federal maupun undang-undang negara bagian, yang bertentangan dengan Konstitusi. Sementara itu, Hakim Agung Amerika Serikat disumpah untuk menegakkan Konstitusi. Oleh karena itu, Marshall menegaskan, jika dalam mengadili suatu kasus berlaku undang-undang yang bertentangan dengan Konstitusi maka sudah sepatutnya Mahkamah Agung memiliki kewenangan untuk mengesampingkan undang-undang tersebut dan menyatakannya bertentangan dengan Konstitusi. 37

Kini, pengadilan-pengadilan di Amerika Serikat -baik pengadilan federal maupun pengadilan negara bagian, lebih-lebih Mahkamah Agung Amerika Serikat- memiliki kewenangan menguji konstitusionalitas undang-undang (judicial review). Berbeda dengan pengujian konstitusional yang dikembangkan dengan mengikuti model Kelsen, yang tidak mensyaratkan adanya kasus konkret, pengadilan-pengadilan di Amerika Serikat mengembangkan model tersendiri yaitu model pengujian konstitusionalitas undang-undang dengan yang bertolak dari kasus-kasus konkret. 3839

Secara historis, dasar pemikiran seperti yang diuraikan di atas juga menjadi rujukan ketika Majelis Permusyawaratan Rakyat mengadopsi gagasan membentuk Mahkamah Konstitusi melalui perubahan UUD 1945. ${ }^{40}$ Dalam Pasal 24 ayat (2) UUD 1945 menegaskan kedudukan MK dalam sistem ketatanegaraan Indonesia menurut UUD 1945 sebagai salah satu pelaku kekuasaan kehakiman selain Mahkamah Agung

${ }^{33}$ Donald P Kommers and Russell A Miller, The Constitutional Jurisprudence of the Federal Republic of Germany (Duke University Press, 2012).

${ }^{34}$ Kelsen, "General Theory of Law And State, Translated by Anders Wedberg, New York: Russell \& Russell A Division of Atheneum Publishers."

35 Palguna, Pengaduan Konstitusional (Constitutional Complaint): Upaya Hukum Terhadap Pelanggaran Hak-Hak Konstitusional Warga Negara.

${ }^{36}$ Sara Lagi, "Hans Kelsen and the Austrian Constitutional Court (1918-1929)," Co-Herencia9, no. 16 (2012):273-95.

${ }^{37}$ Robert Lowry Clinton, Marbury v. Madison and Judicial Review (University Press of Kansas, 1989).

38 Jimly Asshiddiqie, “Model-Model Pengujian Konstitusional Di Berbagai Negara," 2005.

39 Alec Stone and Alec Stone Sweet, The Birth of Judicial Politics in France: The Constitutional Council in Comparative Perspective (Oxford University Press on Demand, 1992).

40 Palguna, Pengaduan Konstitusional (Constitutional Complaint): Upaya Hukum Terhadap Pelanggaran Hak-Hak Konstitusional Warga Negara. 
(beserta pengadilan-pengadilan di bawahnya dalam empat lingkungan peradilan, yaitu lingkungan peradilan, lingkungan peradilan peradilan agama, lingkungan peradilan militer, dan lingkungan peradilan tata usaha negara). Sebagai pengadilan, kewenangan Mahkamah Konstitusi dinyatakan secara eksplisit dalam Pasal 24C ayat (1) dan ayat (2) UUD 1945 yang berbunyi:

(1) “Mahkamah Konstitusi berwenang mengadili pada tingkat pertama dan terakhir yang putusannya bersifat final untuk menguji undang-undang terhadap Undang-Undang Dasar, memutus sengketa kewenangan lembaga negara yang kewenangannya diberikan oleh Undang-Undang Dasar, memutus pembubaran partai politik, dan memutus perselisihan tentang hasil pemilihan umum;"

(2) "Mahkamah Konstitusi wajib memberikan putusan atas pendapat Dewan Perwakilan Rakyat mengenai dugaan pelanggaran oleh Presiden dan/atau Wakil Presiden menurut Undang-Undang Dasar;"

(3) $\ldots .$.

Dengan rumusan demikian, terlihat jelas kewenangan Mahkamah Konstitusi bersangkut-paut erat, bahkan langsung berkenaan, dengan soal-soal politik. Dengan memberikan kewenangan demikian kepada Mahkamah Konstitusi berarti UUD 1945 memerintahkan agar soal-soal yang bersangkut paut atau berkenaan dengan soal-soal politik sebagaimana tertuang dalam Pasal 24C ayat (1) dan ayat (2) tersebut diselesaikan melalui proses pengadilan, bukan proses politik. Itulah sebabnya mekanisme ini dikatakan sebagai judicialization of politics - yang harus dibedakan dengan politization of the judiciary. Istilah yang disebut terakhir ini merujuk pada "rusaknya" prinsip kemerdekaan kekuasaan kehakiman atau peradilan (the independence of the judiciary) yang disebabkan oleh adanya internvensi politik. ${ }^{41}$

Dengan menelaah secara saksama kewenangan MK sebagaimana diberikan Konstitusi, secara implisit berarti MK berfungsi sebagai penafsir Konstitusi (UUD 1945). Oleh karena itu, menurut Jimly Asshiddiqie, dalam setiap putusan atas kasus yang diajukan kepadanya, lebih-lebih dalam pengujian undang-undang terhadap UUD 1945, pada hakikatnya Mahkamah Konstitusi senantiasa melakukan kegiatan penafsiran konstitusi. ${ }^{2}$ Dengan memberikan fungsi sebagai penafsir Konstitusi kepada Mahkamah Konstitusi maka berarti dalam menegakkan prinsip supremasi konstitusi (yang mulai dianut setelah dilakukannya perubahan terhadap UUD 1945), Indonesia melakukannya melalui penerapan prinsip supremasi pengadilan (judicial supremacy). Penerapan prinsip supremasi pengadilan dalam penafsiran konstitusi, menurut Keith Whittington, adalah pilihan yang paling tepat sebab jika penafsiran konstitusi diserahkan kepada lembaga-lembaga politik maka yang akan terjadi adalah pertikaian politik yang tak berkesudahan.43.

Pasal 24C ayat (1) UUD 1945 menegaskan putusan Mahkamah Konstitusi bersifat final. Hal ini juga berlaku di seluruh dunia yang melembagakan mahkamah konstitusi (atau

${ }^{41}$ Martin Belov, Courts, Politics and Constitutional Law: Judicialization of Politics and Politicization of the Judiciary (Routledge, 2019).

42 Jimly Asshiddiqie, Pokok-Pokok Hukum Tata Negara Indonesia Pasca Reformasi (Bhuana Ilmu Populer, 2007).

${ }^{43}$ Keith E Whittington, Political Foundations of Judicial Supremacy (Princeton University Press, 2009). 
sebutan lainnya) dalam sistem ketatanegaraannya. ${ }^{44}$ Artinya, tidak terdapat upaya hukum apa pun yang dapat ditempuh untuk mengubah putusan Mahkamah Konstitusi. Karena itu, sebagaimana ditegaskan dalam Pasal 47 Undang-Undang Nomor 24 Tahun 2003 tentang Mahkamah Konstitusi sebagaimana telah diubah terakhir dengan Undang-Undang 7 Tahun 2020 tentang Perubahan Ketiga UndangUndang Nomor 24 Tahun 2003 tentang Mahkamah Konstitusi (selanjutnya disebut UU MK), Putusan Mahkamah Konstitusi memperoleh kekuatan hukum tetap sejak selesai diucapkan dalam sidang pleno terbuka untuk umum. Sementara itu, dalam Pasal 57 ayat (7) UU MK ditegaskan putusan Mahkamah Konstitusi yang mengabulkan permohonan wajib dimuat dalam Berita Negara dalam jangka waktu paling lambat tiga puluh hari sejak putusan diucapkan.

Ketentuan yang tertuang dalam UU MK tersebut, secara hakiki menegaskan nature Mahkamah Konstitusi sebagai negative legislator jika dibandingkan dengan pembentuk undang-undang sebagai positive legislator. Jika undang-undang (yang merupakan produk positive legislator) wajib dimuat dalam Lembaran Negara, putusan Mahkamah Konstitusi (yang merupakan produk negative legislator) dimuat dalam Berita Negara. Baik Lembaran Negara maupun Berita Negara memiliki fungsi yang sama yaitu fungsi publikasi yang maksudnya agar setiap orang tahu. Jika undang-undang (pada umumnya) dinyatakan mulai berlaku sejak saat diundangkan dalam lembaran negara, putusan Mahkamah Konstitusi mulai berlaku sejak saat selesai diucapkan dalam sidang pleno terbuka untuk umum (dan kemudian dimuat dalam Berita Negara). Dengan memiliki kewenangan memeriksa dan memutus perkara judicial review, sebagaimana telah dijelaskan sebelumnya, maka kekuatan mengikat putusan MK sama dengan kekuatan mengikat undang-undang.

Dengan demikian, menurut sistem ketatangeraan Indonesia yang berlaku saat ini, putusan Mahkamah Konstitusi memiliki kedudukan sebagai putusan negative legislator dan sekaligus putusan dari penafsir Konstitusi. Sebagai putusan negative legislator, konsekuensinya, pelanggaran terhadap putusan Mahkamah Konstitusi sama derajatnya dengan pelanggaran terhadap undang-undang (produk positive legislator). Sementara itu, sebagai putusan penafsir Konstitusi maka putusan Mahkamah Konstitusi, c.q. dalam pengujian undang-undang terhadap UUD 1945, pada hakikatnya adalah penafsiran Mahkamah terhadap Konstitusi yang seharusnya diturunkan ke dalam substansi undang-undang tersebut. Oleh karena itu, ketidaktaatan terhadapnya sama artinya dengan melakukan pembangkangan terhadap Konstitusi.

3.2. Upaya hukum yang dapat ditempuh oleh warga negara Indonesia penghayat kepercayaan yang hak konstitusionalnya sebagai penghayat kepercayaan tetap dirugikan meskipun telah ada Putusan Mahkamah Konstitusi Nomor 97/PUUXIV/2016

Sebelum menjawab isu hukum sebagaimana tertera pada angka 3.2. di atas, oleh karena yang menjadi pokok soal adalah bersangkut-paut dengan penghormatan, perlindungan, dan pemenuhan hak atas kebebasan beragama dan berkeyakinan maka menjadi penting untuk terlebih dahulu meninjau keberadaan hak itu dalam konteks global, sebagaimana diatur dalam instrumen-instrumen internasional tentang HAM.

${ }^{44}$ Andrew Harding, The Fundamentals of Constitutional Courts (Constitutional Brief, IDEA, 2017). 
Universal Declaration of Human Rights (UDHR), 45 Pasal 18 menyatakan, "Everyone has the right to freedom of thought, conscience and religion; this right includes freedom to change his religion or belief, and freedom, either alone or in community with others and public or private, to manifest his religion or belief in theaching, practice, worship and observance" (Setiap orang berhak atas kebebasan pikiran, hati nurani, dan agama; hak ini mencakup kebebasan mengganti agama atau keyakinannya, dan kebebasan untuk menunjukkan agama atau keyakinannya dalam pengajaran, praktik, persembahyangan dan ketaatan, baik secara sendirian maupun bersama-sama dengan orang lain dan umum maupun pribadi).

Sementara itu, International Covenant on Civil and Political Rights (ICCPR), ${ }^{46}$ Pasal 18 menyatakan:

1) Setiap orang berhak atas kemerdekaan pikiran, keyakinan dan agama. Hak ini mencakup kebebasan untuk memiliki atau menerima suatu agama atau kepercayaan atas pilihannya, dan kebebasan, baik secara sendiri-sendiri maupun bersama-sama dengan orang lain dan di hadapan umum maupun di ruang pribadi, untuk menunjukkan agama atau kepercayaannya dalam persembahyangan, kepatuhan, praktik dan pengajaran (Everyone shall have the right to freedom of thought, consience and religion, this right shall include freedom to have or to adopt a religion or belief of his choice, and freedom, either individually or in community with others and in public or private, to manifest his religion or belief in worship, observance, practice and teaching).

2) Tak seorang pun boleh ditundukkan pada paksaan yang akan menyederai kebebasannya untuk menganut atau menerima suatu agama atau kepercayaan atas pilihannya sendiri (No one shall be subject to coercion which would impair his freedom to have or to adopt a religion or belief of his choice).

3) Kemerdekaan untuk menunjukkan agama atau keyakinan seseorang hanya dapat ditundukkan pada pembatasan-pembatasan yang ditentukan oleh undang-undang dan diperlukan untuk melindungi keselamatan umum, ketertiban, kesehatan, atau moral atau hak-hak dan kebebasan-kebebasan mendasar orang lain (Freedom to manifest one's religion or beliefs may be subject only to such limitations as are prescribed by law and are necessary to protect public safety, order, health, or morals or the fundamental rights and freedoms of others).

4) Negara-negara Pihak dalam Kovenan ini sepakat untuk memberikan penghormatan terhadap kebebasan orang tua dan, bilamana dapat diterapkan, wali yang sah guna menjamin pendidikan agama dan moral anak-anak mereka sesuai dengan keyakinan mereka sendiri (The States Parties to present Covenant undertake to have respect for the liberty of parents and, when applicable, legal guardians to ensure the religious and moral education of their children in conformity with their own convictions).

45 United Nation, "Universal Declaration of Human Rights," United Nation, 2015, https://www.un.org/en/udhrbook/pdf/udhr_booklet_en_web.pdf.

46 United Nation, "International Covenant on Civil and Political Rights," United Nation, 1976, https:/ / treaties.un.org/doc/publication/ unts/volume 999/volume-999-i-14668-english.pdf. 
Selanjutnya, United Nations Declaration on the Elimination of All Forms of Intolerance and Discrimination Based on Religion or Belief (selanjutnya disebut Deklarasi), sebagaimana tertuang dalam Resolusi Majelis Umum PBB Nomor 36/55 tanggal 25 November 1981,47 memerinci lebih lanjut sekaligus menegaskan hal-hal yang disebutkan dalam UDHR dan ICCPR di atas. Pasal 1 Deklarasi mengulangi substansi yang termuat dalam Pasal 18 UDHR dan Pasal 18 ICCPR. Adapun Pasal 2 Deklarasi yang terdiri atas dua ayat memuat ketentuan bahwa tidak seorang pun boleh dipaksa tunduk pada diskriminasi oleh negara, lembaga, kelompok orang, atau orang karena alasan agama atau kepercayaan orang itu. Kemudian, ayat (2) dari Pasal 2 Deklarasi memberikan pengertian tentang intoleransi dan diskriminasi atas dasar agama atau kepercayaan yaitu setiap pembedaan, pengucilan, pembatasan atau preferensi yang didasarkan atas agama atau kepercayaan yang mengandung maksud atau pengaruh peniadaan atau pelemahan pengakuan, penikmatan atau pelaksanaan hak-hak asasi dan kebebasankebebasan mendasar yang didasarkan atas prinsip persamaan (any distinction, exclusion, restriction or preference based on religion or belief and having as its purpose or as its effect nullification or impairment of the recognition, enjoyment or exercise of human rights and fundamental freedoms on an equal basis).

Sementara itu, melalui Pasal 3-nya, Deklarasi menegaskan bahwa diskriminasi umat manusia atas dasar agama dan kepercayaan adalah penghinaan terhadap martabat manusia dan pengingkaran terhadap prinsip-prinsip Piagam PBB, karena itu harus dikecam sebagai pelanggaran terhadap hak-hak asasi dan kebebasan-kebebasan mendasar, sebagaimana diumumkan dalam UDHR dan dinyatakan secara lebih rinci dalam ICCPR, serta sebagai hambatan terhadap hubungan yang bersahabat dan damai antarbangsa. Ketentuan ini menunjukkan betapa seriusnya masyarakat internasional memandang dampak dari diskriminasi atas dasar agama atau kepercayaan itu.

Lebih lanjut, Pasal 6 Deklarasi menyebutkan jenis-jenis kebebasan atau kemerdekaan yang tercakup dalam pengertian "hak atas kemerdekaan pikiran, hati nurani, agama atau kepercayaan", di antaranya:

(a) untuk beribadah dan berkumpul dalam kaitannya dengan suatu agama atau kepercayaan dan untuk mendirikan serta memelihara tempat-tempat untuk maksud ini (to worship or assemble in connection with a religion or belief, and to establish and maintain places for these purposes);

(b) untuk mendirikan dan memelihara lembaga-lembaga derma atau kemanusiaan yang sesuai (to establish and maintain appropriate charitable or humanitarian institutions);

(c) untuk membuat, mempunyai dan menggunakan dalam batas yang patut benda-benda dan bahan-bahan yang diperlukan sehubungan dengan ritusritus atau kebiasaan-kebiasaan dari suatu agama atau kepercayaan (to make, acquire and use to an adequate extent the necessary articles and materials related to the rites or customs of a religion or belief);

(d) untuk menulis, menerbitkan dan menyebarluaskan terbitan-terbitan yang relevan dalam bidang ini (to write, issue and disseminate relevant publications in these areas);

${ }^{47}$ United Nation Human Rights, "OHCHR | Declaration on the Elimination of All Forms of Intolerance," United Nation Human Rights, accessed September 24, 2021, https://www.ohchr.org/en/professionalinterest/pages/religionorbelief.aspx. 
(e) untuk mengajarkan suatu agama atau kepercayaan di tempat-tempat yang sesuai untuk maksud ini (to teach a religion or belief in places suitable for these purposes);

(f) untuk mengumpulkan dan menerima kontribusi keuangan dan kontribusi lain yang bersifat sukarela dari perorangan maupun lembaga (to solicit and receive voluntary financial and other contributions from individuals and institutions);

(g) untuk melatih, mengangkat, memilih atau menunjuk melalui pergantian pemimpin yang tepat yang diperlukan sesuai dengan persyaratan dan standar setiap agama atau kepercayaan (to train, appoint, elect or designate by succession appropriate leaders called for by the requirements and standards of any religion or belief);

(h) untuk menghormati hari-hari libur dan untuk merayakan hari-hari serta upacara-upacara suci menurut ajaran suatu agama atau kepercayaan (to observe days of rest and to celebrate holidays and ceremonies in accordance with the precepts of one's religion or belief);

(i) untuk membangun dan memelihara komunikasi dengan perorangan dan komunitas dalam masalah-masalah agama atau kepercayaan pada tingkat nasional maupun internasional (to establish and maintain communications with individuals and communities in matters of religion or belief at the national and international levels).

Jenis-jenis kebebasan atau kemerdekaan tersebut tidak bersifat limitatif sebab Pasal 6 Deklarasi menggunakan frasa "shall include, inter alia, ..." (mencakup, antara lain, ...). Artinya, Pasal 6 tidak menutup aspek-aspek kebebasan atau kemerdekaan lain yang terkandung dalam ruang lingkup "hak atas kemerdekaan pikiran, hati nurani, agama atau kepercayaan.

Uraian yang bertolak dari tiga instrumen hak asasi manusia internasional di atas diperlukan karena, sepanjang berkenaan dengan ICCPR, Indonesia telah menjadi negara pihak (state party) dengan meratifikasinya melalui Undang-Undang Nomor 12 Tahun 2005 tentang Pengesahan International Covenant on Civil and Political Rights (Kovenan Internasional tentang Hak-hak Sipil). ${ }^{48}$ Oleh karena itu, sesuai dengan prinsip Pacta Sunt Servanda, sebagaimana tertera dalam Pasal 26 dan Pasal 27 Konvensi Wina 1969 tentang Hukum Perjanjian Internasional, Indonesia memiliki kewajiban hukum internasional (international legal obligation) untuk melaksanakan ketentuanketentuan atau isi ICCPR dengan itikad baik. Kewajiban-kewajiban itu, di antaranya, dinyatakan secara tegas dalam Pasal 2 ayat (3) ICCPR yang menyatakan bahwa negara-negara pihak dalam Kovenan ini (a) sepakat untuk menjamin bahwa setiap orang yang hak-hak atau kebebasan-kebebasannya diakui dalam Kovenan ini dilanggar harus memiliki sarana pemulihan yang efektif, kendatipun pelanggaran tersebut dilakukan oleh orang-orang yang bertindak dalam suatu kapasitas resmi (to ensure that any person whose rights or freedoms as herein recognized are violated shall have an effective remedy, notwithstanding that the violation has been committed by persons acting in an official capacity); (b) sepakat untuk menjamin bahwa setiap orang yang menuntut pemulihan demikian hak-haknya harus diputuskan oleh otoritas pengadilan,

${ }^{48}$ Lembaran Negara Republik Indonesia Tahun 2005 Nomor 119, Tambahan Lembaran Negara Republik Indonesia Nomor 4558. 
pemerintahan atau legislatif yang berwenang untuk itu, atau oleh otoritas lain yang berwenang yang disediakan oleh sistem hukum negara yang bersangkutan, dan untuk mengembangkan kemungkinan-kemungkinan pemulihan melalui proses peradilan (to ensure that any person claiming such a remedy shall have his right thereto determined by competent judicial, administrative or legislative authorities, or by any other competent authority provided for by the legal system of the State, and to develop the possibilities of judicial remedy); (c) sepakat bahwa otoritas yang berwenang harus menegakkan pemulihan tersebut jika dikabulkan (to ensure that the competent authorities shall enforce such remedies when granted).

Sementara itu, dalam kaitannya dengan UDHR dan khususnya United Nations Declaration on the Elimination of All Forms of Intolerance and Discrimination Based on Religion or Belief, meskipun bentuknya deklarasi yang - dalam konteks sumber hukum internasional yang mengacu pada Pasal 38 ayat (1) Statuta Mahkamah Internasional belum dapat dikategorikan sebagai sumber hukum internasional, namun deklarasi itu diterima melalui Resolusi Majelis Umum PBB. Berdasarkan Pasal 7 ayat (1) Piagam PBB, Majelis Umum adalah salah satu organ utama (principal organ) PBB. Keanggotaanya, sebagaimana ditegaskan dalam Pasal 9 ayat (1) Piagam PBB, meliputi seluruh negara anggota PBB. Dengan demikian tidaklah berlebihan jika dikatakan bahwa Resolusi yang dikeluarkan oleh Majelis Umum PBB mencerminkan pendapat seluruh negara anggota PBB, yang di dalamnya tentu saja termasuk Indonesia. Karena itu, bagi Indonesia, setidak-tidaknya terdapat kewajiban moral untuk menaatinya.

Pada sub-bab 3.1. telah ditegaskan bahwa putusan Mahkamah Konstitusi dalam pengujian undang-undang terhadap UUD 1945 adalah putusan dari negative legislator yang kekuatannya mengikatnya sama dengan kekuatan mengikat undang-undang. Oleh karena itu, tidak mematuhi putusan Mahkamah Konstitusi sama kualifikasinya dengan tidak mematuhi undang-undang. Lebih jauh lagi, oleh karena Mahkamah Konstitusi adalah penafsir Konstitusi (UUD 1945), maka putusannya (c.q. putusan dalam perkara pengujian undang-undang terhadap UUD 1945) pada hakikatnya bermuatan penafsiran konstitusional Mahkamah Konstitusi terhadap norma undangundang yang dimohonkan pengujian. Oleh karena itu, mengabaikan putusan Mahkamah Konstitusi juga dapat dikategorikan sebagai kesengajaan membangkang terhadap Konstitusi (UUD 1945).

Hak untuk menganut agama atau kepercayaan - yang substansinya mencakup ruang lingkup sebagaimana tertuang dalam tiga instrumen internasional hak asasi manusia di atas - telah dimasukkan ke dalam UUD 1945, sebagaimana dapat dibaca dalam Pasal 28E ayat (2) serta Pasal 28I ayat (1) UUD 1945. Sebagai Konstitusi, UUD 1945 adalah hukum fundamental, the supreme law, di Indonesia. Oleh karena itu, sebagaimana telah disinggung sebelumnya, dengan memasukkan hak-hak asasi manusia, termasuk dalam hal ini hak untuk menganut agama atau kepercayaan, ke dalam UUD 1945 berarti telah memberikan status hak konstitusional kepada hak-hak tersebut. Dengan status demikian, hak-hak itu kini menjadi bagian dari hukum fundamental. Oleh sebab itu, pelanggaran terhadapnya adalah pelanggaran terhadap hukum fundamental dan karenanya harus dapat dibatalkan melalui putusan pengadilan. ${ }^{4950}$ Inilah yang menjadi landasan penalaran dijadikannya adanya dugaan pelanggaran terhadap hak konstitusional sebagai syarat untuk dapat dilakukannya

49 Basu, Banerjee, and Massey, Human Rights in Constitutional Law.

${ }^{50}$ Louis Henkin, Human Rights (New York: Foundation Press, 1999). 
pengujian terhadap undang-undang, baik pengujian yang bertolak dari kasus-kasus konkret seperti yang diterapkan di Amerika Serikat maupun yang tanpa mensyaratkan kasus konkrit seperti yang dipraktikkan di Indonesia dengan banyak negara lainnya.

Bertolak dari seluruh uraian pada sub-bab ini dan dalam konteks perlindungan terhadap hak konstitusional penghayat kepercayaan pasca-Putusan Mahkamah Konstitusi Nomor 97/PUU-XIV/2016, hal penting yang harus digarisbawahi ialah adanya dua kewajiban hukum yang kepada negara dituntut pemenuhannya. Pertama, kewajiban hukum internasional yang diturunkan dari keikutsertaan Indonesia sebagai negara pihak (state party) pada ICCPR. Kedua, kewajiban hukum yang diturunkan dari ketentuan Konstitusi (UUD 1945), sebagaimana telah diputus oleh Mahkamah Konstitusi lewat putusannya yang bersifat final dan berkekuatan hukum tetap.

Dengan adanya dua kewajiban hukum yang harus dipenuhi oleh negara tersebut dan berhubung di Indonesia belum diadopsi mekanisme pengaduan konstitusional maka bagi warga negara Indonesia penghayat kepercayaan yang tetap diperlakukan diskriminatif meskipun telah ada Putusan Mahkamah Konstitusi Nomor 97/PUUXIV/2016 tersedia beberapa mekanisme hukum yang dapat ditempuh:

- Pertama, warga negara Indonesia penghayat kepercayaan dapat mengajukan gugatan warga negara (citizen lawsuit atau citizen suit) dengan tuntutan agar pengadilan memerintahkan kepada pemerintah untuk melaksanakan Putusan MK a quo sebagaimana mestinya; konkretnya, tuntutan untuk tidak lagi mengosongkan kolom agama pada KTP warga negara Indonesia penghayat kepercayaan melainkan mencantumkan "penghayat kepercayaan" pada kolom dimaksud. Meskipun mula-mula gugatan warga negara ini diintroduksi dalam hukum lingkungan, 5152 khususnya di Amerika Serikat dan secara spesifik pada masa kejayaan keberlakuan sejumlah undang-undang anti-polusi, seperti the Clean Water and the Clean Air Act, ${ }^{53}$ jika merujuk pada praktik atau kenyataan empirik di Indonesia, hingga saat ini sudah banyak gugatan warga negara yang diterima pengajuannya oleh pengadilan-pengadilan di Indonesia, terlepas dari apa pun amar putusannya. Misalnya, Putusan Pengadilan Negeri Jakarta Pusat Nomor 28/Pdt.G/2003/PN.Jkt.Pst. (gugatan perkara buruh migran yang dideportasi di Nunukan); Putusan Pengadilan Negeri Jakarta Pusat Nomor 228/Pdt.G/ 2006/PN.Jkt/Pst (perkara Ujian Nasional); Putusan Pengadilan Negeri Jakarta Pusat Nomor 278/Pdt.G/2010/PN. Jkt.Pst (perkara penyelenggaraan jaminan sosial).

Gugatan warga negara (citizen lawsuit atau citizen suit) gugatan yang memungkinkan warga negara menuntut atau menggugat pemerintah karena pelanggaran dalam pengertian pemenuhan hak-hak warga negara. Tujuannya adalah guna melindungi warga negara dari kerugian yang disebabkan oleh perbuatan atau kelalaian pejabat negara atau pemerintah. ${ }^{54}$ Dengan bertolak dari pengertian demikian maka menggunakan mekanisme

\footnotetext{
${ }^{51}$ Inc Merriam-Webster, Merriam-Webster's Dictionary of Law (Merriam-Webster, 1996).

${ }^{52}$ Garner, "Black's Law Dictionary Seventh Edition,(St."

${ }^{53}$ Gail J Robinson, "Interpreting the Citizen Suit Provision of the Clean Water Act," Case W. Res. L. Rev. 37 (1986): 515.

${ }^{54}$ Elson, "The Differences between Citizen and Class Action Lawsuits | Elson," Elson, 2019, https:/ / elson.co.id/2019/01/ the-differences-between-citizen-and-class-action-lawsuits/.
} 
gugatan warga negara dalam konteks pemenuhan hak konstitusional warga negara Indonesia penghayat kepercayaan sangat memenuhi syarat karena:

a) yang menjadi tergugat adalah penyelenggara negara;

b) fundamentum petendi atau posita gugatannya adalah kelalaian negara (penyelenggaran pemerintahan) dalam memenuhi hak konstitusional warga negaranya;

c) dari sudut pandang penggugatnya, dalam hal ini penggugat bukan hanya warga negara Indonesia namun sekaligus warga negara Indonesia yang secara faktual mengalami kerugian sebagai akibat tidak terpenuhinya hak konstitusional dirinya;

d) hal yang diminta untuk diputus atau petitum gugatan bukanlah ganti kerugian materiil melainkan dilakukannya tindakan tertentu atau dihentikannya tindakan tertentu, dalam hal ini dihentikannya tindakan diskriminatif terhadap kelompok warga negara Indonesia penghayat kepercayaan.

- Kedua, dalam hal tidak dilaksanakannya Putusan MK a quo menimbulkan kerugian perdata bagi penghayat kepercayaan, mereka dapat mengajukan gugatan perwakilan (class action). 55 Hingga saat ini, di Indonesia, kendatipun dalam praktik makin hari makin banyak jumlah gugatan perwakilan diajukan ke pengadilan, prosedur beracaranya masih diatur dalam Peraturan Mahkamah Agung Nomor 1 Tahun 2002 tentang Acara Gugatan Perwakilan Kelompok (Perma 1/2002). Pasal 1 huruf a Perma 1/2002 memberikan pengertian Gugatan Perwakilan Kelompok sebagai "suatu tata cara pengajuan gugatan, dalam mana satu orang atau lebih yang mewakili kelompok mengajukan gugatan untuk diri atau diri sendiri dan sekaligus mewakili sekelompok orang yang jumlahnya banyak, yang memiliki kesamaan fakta atau dasar hukum antara wakil kelompok dan anggota kelompok dimaksud. Warga negara penghayat kepercayaan jelas memenuhi kriteria ini sepanjang yang mengajukan gugatan (sebagai wakil kelompok) adalah sama-sama penghayat kepercayaan. Kendalanya ialah cara menghitung kerugian perdata yang timbul sebagai akibat dari tidak dilaksanakannya Putusan Mahkamah Konstitusi di atas dan cara mendistribusikan ganti kerugian kepada seluruh anggota kelompok. Kesulitan demikian timbul karena Perma 1/2002 memersyaratkan dikemukakannya petitum atau tuntutan secara jelas dan terperinci, memuat usulan tentang mekanisme atau tata cara pendistribusian ganti kerugian kepada seluruh anggota kelompok, termasuk usulan tentang pembentukan tim atau panel yang membantu memperlancar pendistribusian ganti kerugian. ${ }^{56}$

- Ketiga, masih dalam tidak dilaksanakannya Putusan MK a quo tersebut menimbulkan kerugian perdata bagi penghayat kepercayaan, secara individual atau sendiri-sendiri warga negara Indonesia penghayat

${ }^{5}$ Susanti Adi Nugroho, Class Action \& Perbandingannya Dengan Negara Lain, Cetakan ke (Jakarta:

Kencana Prenada Media Group, 2010).

56Pasal 3 ayat (1) huruf $\mathrm{f}$ Perma 1/2002. 
kepercayaan berhak mengajukan gugatan perdata biasa. Hal ini tentu lebih mudah sebab penggugat (c.q. warga negara Indonesia penghayat kepercayaan) tinggal memerinci kerugian perdata yang timbul sebagai akibat dari tidak diindahkannya Putusan Mahkamah Konstitusi tersebut serta menerangkan hubungan kausal (causal verband) dari timbulnya kerugian perdata dimaksud dengan tidak dilaksanakannya Putusan MK a quo.

- Membuat pengaduan resmi kepada presiden dengan tuntutan agar presiden menegur kepala daerah yang tetap membangkang terhadap Putusan MK a quo. Presiden, yang secara konstitusional sebagaimana diatur dalam Pasal 4 ayat (1) UUD 1945 adalah pemegang kekuasaan pemerintahan, merupakan penanggung jawab tertinggi pelaksanaan kekuasaan pemerintahan di Indonesia. Oleh karena itu, Presiden bukan hanya berwenang menegur tetapi juga menjatuhkan sanksi administratif tertentu kepada pemerintah daerah, baik pemerintah daerah provinsi maupun kabupaten/kota yang tidak mengindahkan putusan Mahkamah Konstitusi dimaksud. Lagi pula, Pasal 28I ayat (4) UUD 1945 tegas mengamanatkan bahwa perlindungan, pemajuan, penegakan, dan pemenuhan hak asasi manusia adalah tanggung jawab negara, terutama pemerintah. Dalam kaitan ini, tindakan tegas yang dilakukan oleh Presiden Amerika Serikat, Dwight D. Eisenhower, kiranya cukup tepat dijadikan contoh sekaligus perbandingan. Sejak ada putusan Mahkamah Agung Amerika Serikat dalam kasus Brown v. Board of Education (1954) seharusnya tidak ada lagi segregasi atas dasar warna kulit di sekolah-sekolah. Namun, ternyata banyak sekolah di negara-negara bagian di selatan yang tidak mematuhi putusan tersebut. Salah satunya yang terkenal ialah "pembangkangan" yang dilakukan oleh Central High School di Little Rock, Arkansas. Para pelajar berkulit hitam dikeluarkan secara paksa dari sekolah itu dan Gubernur Negara Bagian Arkansas tidak melakukan tindakan apa pun terhadap tindakan yang melawan putusan Mahkamah Agung Amerika Serikat itu. Hal ini membuat Presiden Eisenhower marah dan kemudian menandatangani "perintah eksekutif" (executice order) untuk menurunkan tentara nasional guna mengawal anak-anak kulit hitam tersebut ke sekolah. Presiden Eisenhower dengan marah mengatakan, Tatkala negara bagian berusaha menggagalkan perintah pengadilan federal sambil mendorong kelompok-kelompok ekstremis untuk menggagalkan perintah pengadilan federal itu, dan ketika negara bagian menolak menggunakan kekuatan kepolisiannya untuk melindungi orang-orang yang secara damai melaksanakan hak-haknya yang diberikan oleh Konstitusi sebagaimana diputuskan oleh putusan pengadilan maka sumpah jabatan Presiden menuntutnya untuk bertindak guna memberikan perlindungan itu. ${ }^{57}$ Eisenhower menegaskan lebih jauh, Keengganan bertindak dalam kasus demikian sama artinya dengan menerima anarki dan tercerai-berainya persatuan, kata veteran Perang Dunia II ini. ${ }^{58}$

57Untuk uraian selengkapnya, lihat Palguna, I D.G. Pengaduan Konstitusional ...op.cit., h. 388-398.

${ }^{58}$ Ibid., h. 397. 


\section{Kesimpulan}

Pertama, kedudukan putusan Mahkamah Konstitusi dalam sistem ketatanegaraan Indonesia menurut UUD 1945 adalah sederajat dengan undang-undang sebab ia dibuat oleh lembaga negara yang berfungsi sebagai negative legislator. Oleh karena itu, pelanggaran terhadap putusan Mahkamah Konstitusi setara dengan pelanggaran terhadap undang-undang. Bahkan lebih jauh lagi, tidak melaksanakan putusan Mahkamah Konstitusi merupakan pembangkangan terhadap Konstitusi sebab Mahkamah Konstitusi adalah penafsir Konstitusi sehingga putusan-putusannya merupakan wujud penafsiran Mahkamah terhadap Konstitusi (c.q. UUD 1945).

Kedua, yang dapat ditempuh oleh warga negara Indonesia penghayat kepercayaan yang hak konstitusionalnya sebagai penghayat kepercayaan tetap dirugikan meskipun telah ada Putusan Mahkamah Konstitusi Nomor 97/PUU-XIV/2016 terdapat sejumlah alternatif, yaitu (a) mengajukan gugatan warga negara (citizen lawsuit atau citizen suit); (b) mengajukan gugatan perwakilan (class action), dalam hal yang lebih dituju adalah penggantian kerugian; (c) secara individual mengajukan gugatan perdata jika yang dituju adalah penggantian kerugian sementara jika dilakukan melalui class action secara teknis tidak memungkinkan; dan/atau (d) membuat pengaduan resmi kepada presiden agar memerintahkan penyelenggara pemerintahan di bawahnya melaksanakan perintah Putusan Mahkamah Konstitusi Nomor 97/PUU-XIV/2016 sebagaimana mestinya.

\section{Daftar Pustaka}

Asshiddiqie, Jimly. "Model-Model Pengujian Konstitusional Di Berbagai Negara," 2005.

- - - Pokok-Pokok Hukum Tata Negara Indonesia Pasca Reformasi. Bhuana Ilmu Populer, 2007.

Asshiddiqie, Jimly, and Ahmad Syahrizal. Peradilan Konstitusi Di Sepuluh Negara. Sekretariat Jenderal Mahkamah Konstitusi, 2006.

Barber, Steve, and Mark A McCormick. Legal Research. Delmar Pub, 1996.

Basu, Durga Das, Bhagabati Prosad Banerjee, and Ashish Kumar Massey. Human Rights in Constitutional Law. New Delhi-Nagpur-Agra: Wadhwa \& Company, 2003.

Belov, Martin. Courts, Politics and Constitutional Law: Judicialization of Politics and Politicization of the Judiciary. Routledge, 2019.

Clinton, Robert Lowry. Marbury v. Madison and Judicial Review. University Press of Kansas, 1989.

Dahl, Robert A. "Perihal Demokrasi, Terj." A. Rahman Zainuddin, Jakarta: Yayasan. Obor Indonesia, 2001.

Elson. "The Differences between Citizen and Class Action Lawsuits | Elson." Elson, 2019. https://elson.co.id/2019/01/the-differences-between-citizen-and-classaction-lawsuits/.

Garner, Bryan A. "Black's Law Dictionary Seventh Edition,(St." Paul Minn: West Publishing Co, 1999.

Ginsburg, Tom. Judicial Review in New Democracies: Constitutional Courts in Asian Cases. Cambridge University Press, 2003.

H, William. Legal Research. New York: Thomson Delmar Learning, 2006.

Hadjon, Phillipus M., and Tattiek Sri Djatmiati. Argumentasi Hukum. Yogyakarta: 
Gadjah Mada University Press, 2016.

Harding, Andrew. The Fundamentals of Constitutional Courts. Constitutional Brief, IDEA, 2017.

Harkrisnowo, Harkristuti, and et.al. Meretas Khazanah Hukum Indonesia. Depok: Rajawali Pers, 2020.

Held, David. Models of Democracy. Cambridge: Polity Press, 1997.

Henkin, Louis. Human Rights. New York: Foundation Press, 1999.

Kelsen, Hans. "General Theory of Law And State, Translated by Anders Wedberg, New York: Russell \& Russell A Division of Atheneum Publishers." Inc, 1961.

- - - . "Judicial Review of Legislation: A Comparative Study of the Austrian and the American Constitution." The Journal of Politics 4, no. 2 (1942): 183-200.

Kommers, Donald P, and Russell A Miller. The Constitutional Jurisprudence of the Federal Republic of Germany. Duke University Press, 2012.

Lagi, Sara. "Hans Kelsen and the Austrian Constitutional Court (1918-1929)." CoHerencia 9, no. 16 (2012): 273-95.

Maarseveen, H Th J F van, and Ger F M van der Tang. Written Constitutions: A Computerized Comparative Study. Brill, 1978.

Marzuki, Mahmud. Penelitian Hukum: Edisi Revisi. Prenada Media, 2017.

Merriam-Webster, Inc. Merriam-Webster's Dictionary of Law. Merriam-Webster, 1996.

Mersky, Roy M., and Donald J. Dunn. Fundamentals of Legal Research. Eight Edit. New York: Foundation Press, 2002.

Nugroho, Susanti Adi. Class Action E Perbandingannya Dengan Negara Lain. Cetakan ke. Jakarta: Kencana Prenada Media Group, 2010.

Palguna, I Dewa Gede. Pengaduan Konstitusional (Constitutional Complaint): Upaya Hukum Terhadap Pelanggaran Hak-Hak Konstitusional Warga Negara. Jakarta: Sinar Grafika, 2013.

Palguna, I, and Dewa Gede. "Mahkamah Konstitusi: Dasar Pemikiran." Kewenangan, Dan Perbandingan Dengan Negara Lain, Konpress, Jakarta, 2018.

"Para Penghayat Kepercayaan Masih Terpinggirkan - Kompas.Id." Accessed September 24, 2021. https://www.kompas.id/baca/dikbud/2021/05/31/parapenghayat-kepercayaan-masih-terpinggirkan.

"Penghayat Kepercayaan: Sulitnya Kami Menikah Secara "Resmi" - Kompas.Id." Accessed September 24, 2021. https://www.kompas.id/baca/dikbud/2021/05/31/penghayat-kepercayaansulitnya-kami-menikah-secara-resmi.

Robinson, Gail J. "Interpreting the Citizen Suit Provision of the Clean Water Act." Case W. Res. L. Rev. 37 (1986): 515.

Rousseau, Jean-Jacques. "The Social." Contract. London: Penguin Books, 1968.

Sloan, Amy E. Basic Legal Research: Tools and Strategies. Wolters Kluwer, 2018.

Soekanto, Soerjono, and Sri Mamudji. Penelitian Hukum Normatif. Cetakan ke. Jakarta: Raja Grafindo Persada, 1990.

Statsky, William P. Legal Research and Writing: Some Starting Points. West Publishing Company, 1993.

Stone, Alec, and Alec Stone Sweet. The Birth of Judicial Politics in France: The Constitutional Council in Comparative Perspective. Oxford University Press on Demand, 1992

United Nation. "International Covenant on Civil and Political Rights." United Nation, 1976. https://treaties.un.org/doc/publication/unts/volume 999/volume-999-i14668-english.pdf. 
- - . "Universal Declaration of Human Rights." United Nation, 2015. https://www.un.org/en/udhrbook/pdf/udhr_booklet_en_web.pdf.

United Nation Human Rights. "OHCHR | Declaration on the Elimination of All Forms of Intolerance." United Nation Human Rights. Accessed September 24, 2021. https://www.ohchr.org/en/professionalinterest/pages/religionorbelief.aspx.

Walston-Dunham, Beth. Practical Legal Research: Skills $\mathcal{E}$ Strategies for the Legal Assistant. Delmar Pub, 1995.

Whittington, Keith E. Political Foundations of Judicial Supremacy. Princeton University Press, 2009.

William. Great Political Thinkers, Plato to the Present. Third Edit. New York-Chicago-San Francisco-Toronto: Holt, Rinehart and Winston, 1960. 